\title{
PENERAPANAN METODE PEMBIASAAN TOKEN ECONOMY UNTUK PENINGKATAN KEDISIPLINAN ANAK USIA DINI
}

\author{
Wahyuni Nadar'), Tina Maharani²), Shally Shartika ${ }^{3)}$ \\ ${ }^{1}$ STKIP Kusuma Negara \\ email: nadar@stkipkusumanegara.ac.id \\ ${ }^{2}$ STKIP Kusuma Negara \\ email: tinamaharani@stkipkusumanegara.ac.id \\ ${ }^{3}$ STKIP Kusuma Negara \\ email: shallyshartika@gmail.com
}

\begin{abstract}
In general, the purpose of this study is to improve early childhood discipline through the method of token economy habituation in the second semester students of the even semester 2016-2017 SD Cherry South Jakarta. In particular, the discipline referred to in this study is the presence of children on time at school. This research method is classroom action research that follows the model of Kemmis and Taggart. This study consisted of two cycles. Each cycle includes 4 stages, namely 1) planning, 2) implementation, 3) observation, 4) reflection. The research time was 1 month, from April 2017 to May 2017 with the research subjects as many as 11 students, while the data was collected by observation, interviews, and documentation. The results showed that there was a significant increase in discipline in class II students. This can be evidenced by an increase in the results of quantitative calculations ranging from the results of the average pre-action discipline, cycle 1 to cycle 2, namely the results of the average pre-action $=12$, cycle $1=13.27$, cycle $2=15$ and the results of the interviews concluded. that the method of customizing the token economy can optimally motivate early childhood discipline. This study concludes that discipline with the token economy habituation method can improve early childhood discipline.
\end{abstract}

Keywords: discipline, method of token economy habituation, action research

\begin{abstract}
Abstrak
Secara umum tujuan penelitian ini adalah untuk meningkatkan kedisiplinan anak usia dini melalui metode pembiasaan token economy pada siswa kelas II semester genap tahun ajaran 2016-2017 SD Cherry Jakarta Selatan. Secara khusus, kedisiplinan yang dimaksud dalam penelitian ini yaitu kehadiran anak tepat waktu di sekolah. Metode penelitian ini penelitian tindakan kelas yang mengikuti model Kemmis dan Taggart. Penelitian ini terdiri dari dua siklus. Masing-masing siklus mencakup 4 tahap yaitu, yaitu 1) planning (perencanaan), 2) acting (pelaksanaan), 3) observing (observasi), 4) reflecting (refleksi). Waktu penelitian adalah 1 bulan yaitu dari bulan April 2017 sampai bulan Mei 2017 dengan subjek penelitian sebanyak 11 siswa, sedangkan data dikumpulkan dengan observasi, wawancara, dan dokumentasi. Hasil penelitian menunjukkan bahwa terjadi peningkatan kedisiplinan yang signifikan pada siswa kelas II. Hal ini dapat dibuktikan dengan peningkatan hasil perhitungan kuantitatif mulai dari hasil rata-rata kedisiplinan pratindakan, siklus 1 sampai siklus 2 , yaitu hasil rata-rata pratindakan $=12$, siklus $1=13,27$, siklus $2=15$ dan hasil wawancara yang dilakukan menyimpulkan bahwa metode pembiasaan token economy dapat memotivasi kedisiplinan anak usia dini secara optimal. Penelitian ini menyimpulkan bahwa kedisiplinan dengan metode pembiasaan token economy dapat meningkatkan kedisiplinan anak usia dini.
\end{abstract}

Kata kunci: kedisiplinan, metode pembiasaan token economy, penelitian tindakan

\section{PENDAHULUAN}

Akhir-akhir ini timbul banyak kekhawatiran di kalangan masyarakat pada umumnya terhadap pola tingkah laku yang dilakukan sebagian masyarakat yang dianggap telah menyimpang dari nilai-nilali luhur agama, budaya dan falsafah. Bahkan ada yang mengatakan telah terjadi degradasi moral yang sangat parah di dalam masyarakat kita. 
Banyaknya kasus yang menggambarkan kerusakan pada masyarakat kita dari tingkat paling atas sampai dengan lapisan masyarakat paling bawah. Pada lapisan paling atas, kita dapat melihat bagaimana perilaku pemimpin bangsa kita dalam memimpin negara ini. Korupsi, kolusi, nepotisme, perzinahan sampai masalah pemerasan yang banyak dilakukan oleh instansi pemerintahan.

Sementara itu pada lapisan paling bawah, hancurnya moral bangsa ini ditunjukkan dengan merajalelanya berbagai tindakan kejahatan dan kriminal di tengah-tengah masyarakat seperti penipuan, pencurian, perampokan, perkosaan, pembunuhan, kekerasan dan sebagainya.

Sesuai dengan masalah yang dipaparkan diatas, penelitian ini bertujuan untuk mengetahui peranan metode Token Economy dalam meningkatkan kedisiplinan anak usia dini dan cara perapan metode Token Economy dalam meningkatkan kedisiplinan anak usia dini. Penelitian ini dirumuskan berdasarkan masalah yang telah dipaparkan diatas yaitu sebagai berikut:

1. Apakah metode Token Economy dapat meningkatkan kedisiplinan anak usia dini?

2. Bagaimana penerapan metode Token Economy dlam meningkatkan kedispinan anak usia dini?

\section{KAJIAN LITERATUR}

\section{Hakikat Anak Usia Dini}

Anak usia dini adalah sosok individu yang sedang menjalani suatu proses perkembangan dengan pesat dan fundamental. Anak usia dini berada pada rentang usia 0-8 tahun (http: www.naeyc.org). Pada masa ini proses pertumbuhan dan perkembangan dalam berbagai aspek sedang mengalami masa yang cepat dalam rentang perkembangan hidup manusia (Berk,1992:18).

Menurut NAEYC (National Association for the Education of Young Children) anak usia dini adalah anak yang baru dilahirkan sampai usia 8 tahun. Usia ini merupakan usia yang sangat menentukan dalam pembentukan karakter dan kepribadian anak (Masitoh dkk, 2005).

Anak usia dini merupakan individu yang berbeda, unik, dan memiliki karakteristik tersendiri sesuai dengan tahapan usianya. Berdasarkan Undangundang Nomor 20 Tahun 2003 tentang Sistem Pendidikan Nasional berkaitan dengan Pendidikan Anak Usia Dini tertulis pada pasal 28 ayat 1 yang berbunyi "Pendidikan Anak Usia Dini diselenggarakan bagi anak sejak lahir sampai dengan enam tahun dan bukan merupakan prasyarat untuk mengikuti pendidikan dasar".

Masa usia dini merupakan masa keemasan (golden age) dimana stimulasi seluruh aspek perkembangan berperan penting untuk tugas perkembangan selanjutnya. Perlu disadari bahwa masa-masa awal kehidupan anak merupakan masa terpenting dalam rentang kehidupan seseorang anak. Pada masa ini pertumbuhan otak sedang mengalami perkembangan yang sangat pesat (eksplosif).

Pendidikan anak usia dini bertujuan untuk membantu meletakkan dasar ke arah perkembangan sikap, pengetahuan, keterampilan dan daya cipta yang diperlukan oleh anak didik dalam menyesuaikan diri dengan lingkungannya untuk pertumbuhan serta perkembangan selanjutnya.

Berdasarkan uraian di atas dapat disimpulkan bahwa anak usia dini adalah sosok individu yang berbeda, unik dan memiliki karakteristik tersendiri yang sedang menjalani suatu proses perkembangan dengan pesat dan fundamental sesuai dengan tahapan usianya, yaitu antara 0-8 tahun.

\section{Pengertian Disiplin}

Kata disiplin berasal dari bahasa latin"disciplina" yang artinya pemberian instruksi untuk disiplin. Menurut sejarah, disiplin itu sebagai perintah yang dibutuhkan untuk belajar 
dan perintah membawa hasil pembelajaran. Kedisiplinan itu menuntut prioritas, pengaturan, bertahan atas suatu pilihan dan kontrol diri.

Poerwadarminta dalam kamus besar bahasa Indonesia (2005:28) mengartikan disiplin adalah latihan batin dan watak dengan maksud supaya segala perhatian anak selalu mentaati tata tertib di sekolah.

Sedangkan menurut Hurlock (1999: 82) dalam bukunya Perkembangan Anak mengartikan perilaku disiplin yakni perilaku seseorang yang belajar dari atau secara sukarela mengikuti seorang pemimpin. Dalam hal ini anak merupakan murid yang belajar dari orang dewasa tentang hidup menuju ke arah kehidupan yang berguna dan bahagia dimasa datang. Menurut John Garmo, Ph.D kedisiplinan adalah kualitas inti dari tanggung jawab pribadi. Kedisiplinan diri terlihat melalui kerapian, ketepatan waktu, sikap hemat, dan lain-lain.

Ketiga pendapat di atas dapat disimpulkan bahwa disiplin adalah kualitas yang terdapat dalam diri seseorang dalam melaksanakan tata tertib atau peraturan yang harus dilakukan dalam kehidupan sehari-hari untuk mencapai kehidupan yang berguna dimasa yang akan datang. Jadi dapat dikatakan bahwa disiplin berhubungan erat dengan peraturan yang berlaku.

Kedisiplinan memotivasi orang-orang untuk melakukan apa yang meerka tahu, mereka harus lakukan dan di mana mereka menginginkan itu atau tidak. Hal tersebut didasarkan pada penerimaan mereka akan tanggung jawab pribadi mereka dan setiap aspek dalam kehidupannya. Seseorang yang disiplin akan berusaha untuk menjaga emosi dan dorongan hati mereka dengan baik. Sehingga mereka akan menjaga standar perilaku tertentu dan fokus pada tujuannya. Hal ini berarti menyangkal kesenangan diri sendiri dalam rangka mencapai tujuan penting jangka panjang. Kedisiplinan sendiri harus diterapkan dalam semua bidang kehidupan sesuai dengan tujuan hidup yang ingin dicapainya, baik bidang pendidikan, olahraga, musik, bisnis, atau hubungan antar pribadi. Seseorang yang disiplin dapat mengatasi kelemahannya dan berkembang menjadi kekuatan.

\section{Unsur-Unsur Disiplin}

Pada intinya disiplin memiliki unsur-unsur yang saling berkaitan, yaitu:

1. Peraturan

Adalah ketentuan-ketentuan yang telah ditetapkan untuk menata tingkah laku seseorang dalam suatu kelompok, organisasi, institusi atau komunitas. Tujuannya adalah membekali anak dengan pedoman perilaku yang disetujui dalam situasi tertentu(Hurlock, 1999:85). Fungsi peraturan adalah memiliki nilai pendidikan dan membantu mengekang perilaku yang tidak diinginkan.

2. Kebiasaan-kebiasaan

Artinya adalah perilaku yang dilakukan dalam kegiatan seharihari. Dua sifat kebiasaan adalah tradisional dan modern.

3. Hukuman

Hukuman terjadi karenan adanya kesalahan, perlawanan atau pelanggaran yang disengaja. Ini berarti bahwa seseorang mengetahui bahwa perbuatan itu salah namun masih dilakukan (Anonymous, 2003:157). Tujuan dari hukuman adalah menghentikan anak melakukan sesuatu yang tidak sesuai dengan aturan yang berlaku agar anak jera, baik secara biologis maupun psikologis. Fungsi hukuman adalah untuk menghalangi pengulangan tindakan yang tidak diinginkan, untuk mendidik dan memberi motivasi untuk menghindari perilaku yang tidak diterima masyarakat

4. Penghargaan

Penghargaan adalah unsur disiplin yang sangat penting dalam pengembangan diri dan tingkah laku. Penghargaan tidak harus berupa materi seseorang tetapi dapat juga 
berupa kata-kata pujian atau senyuman. Tiga peran penting penghargaan adalah mempunyai nilai mendidik, berfungsi sebagai motivasi untuk mengulangi perilaku yang disetujui dan untuk memperkuat perilaku yang disetujui secara sosial

\section{Manfaat Disiplin}

Menurut John Garmo, Ph.D. bahwa manfaat disiplin adalah membangun kebiasaan baik seseorang,meningkatkan kemampuannya dalam bertahan, serta melindungi orang dari godaan yang membingungkan dan pola hidup yang membahayakan dan tidak seimbang. Orang yang disiplin akan dengan mudah mencapai tujuan hidupnya dibandingkan orang yang tidak disiplin. Begitu juga dengan siswa di sekolah yang memiliki disiplin yang tinggi akan dengan mudah berkosentrasi menerima pelajaran dan menyelesaikan tugas-tugas yang diberikan.

Menurut Seto Mulyadi, ada sepuluh dari manfaat mengajarkan disiplin pada anak usia dini, yaitu

1. Menumbuhkan kepekaan

2. Menumbuhkan kepedulian

3. Mengajarkan keteraturan

4. Menumbuhkan ketenangan

5. Menumbuhkan sikap percaya diri

6. Menumbuhkan kemandirian

7. Menumbuhkan keakraban

8. Membantu perkembangan otak

9. Membantu anak yang sulit

10. Menumbuhkan kepatuhan

Menurut pendapat-pendapat di atas dapat disimpulkan bahwa kedisiplinan merupakan salah satu karakter yang sangat penting dimiliki oleh seorang individu di rumah, lingkungan sekolah ataupun lingkungan masyarakat. Dengan memiliki kedisiplinan,maka akan menciptaka lingkungan yang kondusif untuk membantu perkembangan anak usia dini pada khususnya.

\section{Pengertian Token Economy}

Token economy berarti sebuah sistem yang memberikan suatu penguatan (melalui token atau poin). Dimana sistem atau cara atau metode ini diberikan secara kontinyu dengan membuat suatu penguatan pada prilaku target dan token tersebut dapat ditukar dengan item/hal yang direferensikan. Token economy melibatkan rangsangan yang terkirim(dalam hal ini token) yang mana dapat ditukar dengan item lain yang direferensikan (penguat cadangan). Distribusi perolehan token berupa fungsi yang dikondisikan atau penguat sekunder, mempunyai arti mereka disesuaikan dengan dan secara efektif pada saat mengakses penguat cadangan. Penguat cadangan bukan merupakan penguat primer (yang tidak dikondisikan), namun penguat itu bersifat biologi atau bawaan secara individu atau merupakan kekuatan lain yang dikondisikan (Miller,1997).

\section{Keuntungan Token Economy}

Token economy merupakan hal praktikal, sebab:

a) Secara umum merupakan pengasuh sehari-hari.

b) Menyediakan alternatif untuk pengiriman reguler dari penguat primer yang dikondisikan dan berbiaya tinggi(Miller,1997).

c) Efektif meningkatkan cakupan dari perilaku target(Alberto\&Trautman,2003).

Token economy tanpa diragukan telah berpengaruh pada banyak sekali hal dalam penelitian dan praktek mengenai kebiasaan perilaku (Alberto,Troutman, 2003; Miller, 1997). Menurut Birnbrauer, dkk (MacMillan, 1973: 151), token economy memiliki beberapa keuntungan yakni sebagai berikut:

1) Memberi penguatan dengan segera untuk semua anggota kelompok dengan objek alat yang umum

2) Token tidak dikelola oleh anak-anak sehingga pemberian penguatan tidak tertunda 
3) Karena token seperti layaknya uang, tingkah laku berangsur-angsur terbawa ke alam bawah sadar dan menambah kekuatan penguatan alami, dan

4) Karena token mempunyai variasi penguat yang mem-backup sehingga tidak jenuh.

\section{Prinsip-Prinsip Token Economy}

Token economy pada dasarnya dapat dilakukan dengan beberapa cara, akan tetapi tetap melibatkan beberapa hal, yaitu

a) penentuan perilaku target

b) pemilihan token

c) identifikasi apa yang akan ditawarkan reward dan jumlah token yang dibutuhkan untuk menerima reward.

d) membuat sistem yang mencatat distribusi pembagian token (Sulzer-Azaroff \& Mayer,1991).

\section{Langkah Penerapan Token Economy}

a) Pemberian instruksi dengan seksama untuk menjelaskan dan mengajarkan peraturan, proses dan persyaratan dalam pelaksanaan token ekonomi kepada kedua pihak dan siapa saja yang berpartisipasi ke dalam sistem.

b) Mempersiapkan simbol-simbol, poker chip, stiker icon smiley dan stempel yang akan digunakan sebagai token.

c) Selembar kertas atau kartu sebagai wadah atau tempat menempelkan atau menyimpan token untuk dikalkulasi.

Tanda Check list, chip poker, stiker, smiley faces, dan stempel adalah objek dan simbol yang umum digunakan sebagai token, dan bisa di simpan pada kartu penerimaan atau kertas yang di print khusus dan pada akhirnya dihitung (Alberto \&Troutman, 2003).

Di dalam kelas, guru dapat menggunakan token sebagai usaha untuk merubah perilaku siswa ke arah yang positif. Selain itu token juga dapat dimanfaatkan sebagai cara untuk mengevaluasi perilaku siswa sendiri. Untuk memastikan tidak terjadinya pemalsuan token, maka sebaiknya guru memakai token yang sulit dipalsukan.

Adapun reward yang disukai dan efektif bila memenuhi syarat-syarat berikut: a) tersedia pilihan yang bervariasi

b) boleh memilih secara pribadi sesuai kesukaannya

c) reward segera tersedia saat token dicapai

d) reward menunjukkan kesesuaian hubungan dengan jumlah yang diperjuangkan untuk mendapatkan token.

Pada pelaksanaannya, sejumlah token dapat diambil apabila individu tertarik ke dalam kebiasaan yang tidak diinginkan. Pengembangan rencana untuk menghapuskan token economy yang sedang berlangsung adalah hal yang sangat penting.Menjalankan distribusi token dengan memunculkan hadiah yang lebih alami, seperti berupa pujian dan penguat sosial lainnya, akan menghasilkan perubahan perilaku yang berkelanjutan pada saat token pada akhirnya dihapuskan.

Strategi yang dapat digunakan dalam usaha menghapuskan sistem token adalah

a) Menambah lamanya waktu antara munculnya target perilaku dan berjalannya token

b) Menaikkan jumlah token yang diminta untuk ditukarkan dengan benda lain yang diinginkan dan menyediakan token secara berselang waktunya.

\section{METODE PENELITIAN}

Penelitian ini bertujuan untuk mengetahui apakah metode token economy dapat meningkatkan kedisiplinan pada anak usia dini dengan rentang usia antara 6 sampai dengan 7 tahun. Adapun kedisiplinan yang diharapkan dapat muncul adalah kedisiplinan yang berhubungan dengan kedatangan tepat pada waktunya ke sekolah.

Penelitian ini dilaksanakan di kelas II yaitu pada saat pembelajaran akan dimulai di SD Cherry. Adapun SD tersebut beralamatkan di Jalan Batong Raya No 6 Kelurahan Cilandak Barat 
Kecamatan Cilandak Jakarta Selatan. SD tersebut dipilih sebagai tempat penelitian karena berdasarkan hasil prasurvei yang dilakukan peneliti di SD tersebut melalui hasil observasi secara langsung ditemukan adanya permasalahan dalam kedisiplinan anak terutama pada anak kelas II. Pelaksanaan penelitian ini dilaksanakan pada bulan September-Desember 2016 pada semester ganjil tahun ajaran 2016-2017.

Metode penelitian yang digunakan dalam penelitian ini adalah penelitian tindakan kelas (classroom action reseach yang disingkat $C A R$ ) (Arikunto, 2010: 128). Secara harfiah, penelitian tindakan kelas berasal dari bahasa inggris, yaitu Classroom Action Research yang berarti action research (penelitian dengan tindakan) yang dilakukan oleh guru di kelas atau di sekolah tempat ia mengajar dengan penekanan pada penyempurnaan atau peningkatan proses dan praksis pembelajaran. Singkatnya, PTK merupakan penelitian praktis yang dilakukan di kelas dan bertujuan untuk memperbaiki praktek pembelajaran yang ada. Adapun penelitian yang digunakan dalam penelitian tindakan kelas ini adalah model Kurt Lewin yang kemudian dikembangkan oleh Kemmis dan Mc Taggart.

Keunggulan penelitian ini adalah karena guru dilibatkan dalam penelitian sebagai subjek yang melakukan tindakan, yang diamati, sekaligus yang diminta untuk merefleksikan hasil pengalaman selama melakukan tindakan dan akhirnya diharapkan akan terjadi perubahan dalam diri mereka (self evaluation). Selain itu adalah diharapkan dengan adanya PTK yang berkesinambungan, guru sebagai subjek peneliti dapat semakin percaya diri, mandiri dan semakin berani mengambil resiko dengan mencobakan halhal yang baru yang patut diduga akan memberikan perbaikan serta peningkatan pengetahuan.

\section{Analisis Data}

Analisis data dalam penelitian ini, peneliti menggunakan pendekatan kualitatif. Peneliti terlibat secara langsung dari tahap perencanaan hingga selanjutnya peneliti memantau, mencatat dan mengumpulkan data. Data yang sudah terkumpul kemudian akan dianalisis dan disusun menjadi sebuah laporan hasil penelitian.

\section{HASIL DAN PEMBAHASAN}

Meningkatkan kedisiplinan siswa memerlukan suatu pendekatan yang kreatif, menyenangkan serta bermakna. Bila selama ini untuk meningkatkan kedisiplinan siswa dilakukan dengan cara memberikan hukuman, sehingga hasil kedisiplinan siswa semakin jauh dari harapan. Bahkan diperkirakan adanya perubahan dikarenakan siswa takut pada hukuman yang diberikan. Hal ini tentu saja sangat tidak baik karena dikhawatirkan kedisiplinan yang timbul tidak melekat permanen pada diri siswa akan tetapi hanya bersifat sementara saja.

Melihat dari kenyataan di atas, maka guru haruslah selalu mencari metode yang lebih variatif dan efektif agar siswa dapat memandang kedisiplinan sebagai sesuatu yang mereka perlukan untuk diri mereka bukan sebagai suatu paksaan. Salah satu metode yang dapat diterapkan untuk meningkatkan kedisiplinan siswa adalah dengan pendekatan metode token economy.

Berdasarkan indikator keberhasilan tindakan dalam penelitian ini adanya peningkatan kedisiplinan siswa. Hasil penelitian ini menunjukkkan bahwa kedisiplinan siswa dapat meningkat melalui metode token economy. Hal ini terbukti pada proses tindakan dimana guru menggunakan metode token economy dalam kegiatan awal pembelajaran sehingga dapat merespon siswa yang kedisiplinannya masih kurang. Hal ini dapat dilihat juga dari peningkatan kedisiplinan siswa ketika diberikan perlakuan/tindakan berupa metode token economy pada nilai ratarata pratindakan mendapat $75 \%$ dan meningkat menjadi $82,95 \%$ pada siklus 1 atau terdapat kenaikan $7,95 \%$. Jika dilihat dari kategori kedisiplinan yang 
mengacu pada indikator keberhasilan, kategori baik pada pratindakan sebesar 54,5\% meningkat $9,13 \%$ menjadi $63,63 \%$ pada siklus 1. Berdasarkan dari hasil siklus 1, penelitian tersebut sudah menunjukkan adanya peningkatan. Namun pemberian tindakan belum berhasil sesuai dengan indikator keberhasilan sehingga dilanjutkan ke dalam siklus 2 .

Sebelum melaksanakan siklus 2, peneliti berusaha untuk mengajak peran serta orang tua agar memberi motivasi pada putra putrinya dengan memberi dukungan mempersiapkan keberangkatan siswa ke sekolah dengan maksimal. Hal ini dipandang perlu oleh peneliti demi meningkatkan hubungan komunikasi antara orang tua dan siswa sehingga dapat membantu dalam usaha peningkatan kedisiplinan baik di sekolah maupun di rumah. Pada siklus 2 setelah diberi tindakan, terdapat peningkatan nilai rata-rata dari siklus 1 82,95\% menjadi $93,7 \%$ atau terdapat peningkatan menjadi $10,75 \%$ pada siklus 2. Bila dilihat dari kategori kedisiplinan siswa pada kategori baik dari siklus 1 ke siklus 2 meningkat dari 63,63\% menjadi $90,09 \%$ atau terdapat peningkatan $26,46 \%$.

Berdasarkan hasil yang diperoleh pada setiap siklus dapat dikatakan bahwa penelitian ini sudah berhasil mencapai indikator yang ditentukan, yaitu sudah mencapai $90,09 \%$ dari jumlah siswa menunjukkan perilaku yang ditargetkan yakni kedisiplinan dan nilai rata-rata kedisiplinan siswa mencapai minimal 76\%(berkategori baik).

Dari hasil observasi terhadap kedisiplinan anak usia dini yang menggunakan metode token economy, tampak bahwa aspek yang ada dalam kedisiplinan anak usia dini dari indikator yaitu hadir tepat waktu ke sekolah, patuh pada aturan, percaya diri, dan kemandirian mengalami peningkatan. Hal ini tampak dari meningkatnya jumlah siswa yang mendapat penilaian cukup baik dan kurang baik meningkat menjadi baik pada saat siklus 2 . Dengan diberikan tindakan yang menggunakan metode token economy, siswa tampak bersemangat, senang, dan sangat antusias dalam melaksanakan kedisiplinan di sekolah.

Penggunaan metode token economy secara keseluruhan terbukti sangat efektif meningkatkan kedisiplinan anak usia dini. Dengan rancangan dan perencanaan yang baik, siswa yang datang ke sekolah sering terlambat, kurang patuh terhadap tata tertib, kurang percaya diri, serta kurang mandiri, dapat termotivasi untuk disiplin setiap harinya. Dengan peningkatan kedisiplinan pada anak usia dini, tentu saja sangat berpengaruh terhadap proses pembelajaran selanjutnya.

Metode token economy pada proses pembelajaran anak usia dini merupakan salah satu metode yang strategis. Pembelajaran dengan menggunakan metode token economy akan lebih bermakna, lebih bewarna dan menyenangkan karena metode ini sangat menghargai usaha siswa untuk melakukan suatu perubahan ke arah yang lebih baik. Untuk itu penerapan metode token economy haruslah memenuhi kondisi-kondisi yang dipersyaratkan agar dapat memperoleh hasil yang maksimal. Kondisi-kondisi tersebut adalah:

1. Harus ada usaha dari guru yang lebih terutama yang berkaitan dengan dana dan waktu.

2. Guru dalam menerapkan metode token economy mempunyai komitmen yang tinggi dan memiliki wawasan yang cukup tentang teori yang melandasi metode ini.

3. Harus adanya kerjasama antara sesama guru dalam melaksanakan metode token economy agar berjalan lancar dan dapat tercapai tujuan yang diharapkan dengan efektif dan efisien.

Menurut uraian di atas bahwa metode token economy adalah suatu metode yang pada akhirnya akan menimbulkan motivasi intrinsik pada 
diri siswa akibat adanya penguatan dari luar agar siswa mau melakukan suatu perilaku yang diharapkan oleh lingkungan disekitarnya. Dimana metode token economy ini juga sangat bermanfaat bagi diri siswa terutama dalam meningkatkan kedisiplinan diri.

\section{KESIMPULAN}

Berdasarkan hasil penelitian dan pembahasan, maka kesimpulan yang dapat diambil dalam penelitian ini adalah sebagai berikut, penerapan metode token economy dapat meningkatkan kedisiplinan pada siswa kelas II SD Cherry. Hal ini dapat dilihat dari peningkatan skor rata-rata kedisiplinan siswa tiap siklusnya. Nilai rata-rata kedisiplinan pratindakan $75 \%$ berkategori cukup, siklus 1 sebesar 82,95\% berkategori baik, dan pada siklus 2 sebesar 90,09\% berkategori baik.

Kenaikan presentase dari pratindakan dan setelah setelah siklus 1 mencapai angka $7,95 \%$ artinya terdapat peningkatan yang cukup baik setelah diterapkannya metode ini. Sedangkan pada siklus 2 terjadi peningkatan $15.09 \%$ dari $75 \%$ pratindakan sehingga menjadi 93,7\%. Dengan demikian tentu hal tersebut merupakan perubahan positif yang sangat signifikan. Artinya keberadaan metode token economy jika dilakukan untuk meningkatkan kedisiplinan siswa sangat efektif dan tentu saja akan sangat berdampak positif bagi siswa.

\section{UCAPAN TERIMA KASIH}

Penulis ingin mengucapkan terima kasih kepada semua pihak yang secara langsung maupun tidak langsung memberikan kontribusi dalam penyelesaian skripsi ini. Secara khusus pada kesempatan ini, penulis berterima kasih kepada Allah SWT yang telah memberikan kesehatan, kemudahan, kelancaran, dan kesabaran dalam menyusun skripsi ini. Dan ucapan terima kasih yang tulus kepada: Dr. H. Susilo, M.M. selaku Ketua STKIP Kusuma Negara Jakarta, Dr. H. Kusrin, M.Pd. selaku Pembantu Ketua I Bidang Akademik, Dr. Evayenni, M.Pd. selaku Ketua Program PAUD STKIP Kusuma Negara, Dr.Asep Saepudin,M.Pd. dan seluruh dosen dan staf Prodi PAUD STKIP Kusuma Negara Jakarta yang memberikan kontribusi dan sumbangsihnya dalam penyelesaian karya ilmiah ini, Dra. $\mathrm{Hj}$. Endah Rasjidah selaku Kepala Sekolah SD Cherry yang telah memberikan kesempatan kepada penulis untuk meneliti di SD Cherry dan seluruh guru dan staf SD Cherry tahun ajaran 2016-2017 yang selalu membantu dan mendoakan kelancaran penyusunan karya ilmiah ini.

\section{REFERENSI}

Arikunto, Suharsimi. 2006. Prosedur Penelitian suatu Pendekatan Praktek. Jakarta:Rineka Cipta.

Badudu, J, J. 2015. Kamus Besar Bahasa Indonesia, Jakarta: Balai Pustaka.

Corey, Gerald. 2005. Teori dan Praktek Konseling dan Terapi, Bandung: Refika Aditama.

Fairbanks, Sarah, dan George Sugai. Token Economy. University of Connecticut

Fisher, Piazza, dan Roane. Handbook of Applied Behavior Analysis

Garmo, John. 2013. Pengembangan Karakter untuk Anak. Jakarta:Kesaint Blanc

Hurlock, Elizabeth, B. 1980. Psikologi Perkembangan. Jakarta: Erlangga.

Majid, Abdul. 2012 Belajar dan Pembelajaran Pendidikan Agama Islam. Bandung: Rosda

Model Pembinaan Pendidikan Karakter di Lingkungan Sekolah, 2010. Direktorat Jenderal Manajemen Pendidikan Dasar dan Menengah 
Papalia, Olds, Feldman. 2009. Perkembangan Manusia. Jakarta: Salemba Humanika.

Pedoman Akademik STKIP Kusuma Negara Tahun Akademik 2015.

Poerwadarminta,W, J, S. 1984. Kamus Umum Bahasa Indonesia. Jakarta: Balai Pustaka.

Saepudin, Asep. 2014. Kumpulan Bahan Perkuliahan PTK.

Sugiyono. 2015. Metode Penelitian Pendidikan. Bandung: Alfabeta.

Sujiono, Yuliani, N. 2007. Metode Pengembangan Kognitif. Jakarta: UT.

UU Nomor 20 Tahun 2013 tentang Sistem Pendidikan Nasional

Winata Putra, Udin, dkk. 2008. Teori Belajar dan Pembelajaran. Jakarta: Universitas Terbuka. 
Jurnal Instruksional, Volume 1, Nomor 1, Oktober 2019 |65 